\title{
Ecological assessment of an intermittent Mediterranean river using community structure and function: evaluating the role of different organism groups
}

\author{
SAMANTHA JANE HUGHES*, ${ }^{*}$, JOSÉ MARIA SANTOS*, MARIA TERESA FERREIRA*, RUTE \\ CARAÇA ${ }^{\ddagger}$ AND ANA M. MENDES* \\ *Forest Research Centre, Superior Agronomy Institute, Technical University of Lisbon, Lisbon, Portugal \\ ${ }^{+}$Centre for Macaronesian Studies, University of Madeira, Funchal Portugal \\ ${ }^{\ddagger}$ Centre for Applied Agricultural Botany, Superior Agronomy Institute, Technical University of Lisbon, Lisbon, Portugal
}

\section{SUMMARY}

1. Reliable lotic ecological monitoring requires knowledge of river typology, environmental factors, the effect of stressors known here as 'pressures' and appropriate indicators of anthropogenically induced change. We sampled benthic macroinvertebrate, fish, bird and macrophyte communities along an intermittent Mediterranean river and analysed community structure (relative abundance) and function (metrics) relative to environmental and pressure gradients in order to identify suitable indicator group(s) for future monitoring and mitigation programmes.

2. Principal components analysis revealed that scale-dependent longitudinal differences in valley form separated narrower higher lying sites and tributaries with good quality habitats from more open degraded sites lower down the river continuum on a small floodplain and large scale pressures describing changes in land use related to agriculture with associated physical bankside and channel impacts.

3. Forward selection of variables in redundancy analysis (RDA) showed that reach scale environmental variables were selected more frequently than pressure variables for each organism group. Altitude and $\mathrm{pH}$ were highly redundant within and between groups, indicating essentially longitudinal structural and functional distribution patterns. Redundancy was far lower between selected pressure variables, but single or no pressure variables were retained for some organism groups indicating poor association of functional data, in particular, with the identified pressures. All RDA results indicated a longitudinal $\mathrm{pH}$ gradient, highlighting the combined effect of multiple environmental and pressure based mechanisms on organism groups.

4. Large, mobile organisms such as fish and birds provided a reliable link between organism structure and function, environmental factors and physical disturbance of the channel, bankside and wider river corridor. Benthic macroinvertebrate and macrophyte structural data revealed distribution patterns in relation to water velocity, a key parameter for developing appropriate compensation measures.

5. Results clearly show the importance of assessing patterns of both functional and structural change across multiple organism groups in order to identify typologically

Correspondence: Samantha Jane Hughes, Forest Research Centre, Technical University of Lisbon, Tapada da Ajuda, 1349-017, Lisbon, Portugal. E-mail: sammyno1@isa.utl.pt 
appropriate links with complex environmental and pressure gradients and develop and implement appropriate monitoring systems.

Keywords: bioassessment, birds, fish, function, macroinvertebrates, macrophytes, Mediterranean rivers, structure

\section{Introduction}

Ecological assessment methods of lotic systems have tended to focus on single groups, in particular benthic macroinvertebrates, fish, diatoms and macrophytes (Barbour et al., 1999; Furse et al., 2006). More recently, the wider stream environment has been successfully assessed using birds (Bryce, Hughes \& Kaufmann, 2002; Vaughn, Noble \& Ormerod, 2007b). Given the hierarchical, multivariate complexity of river systems, it could be argued that single group monitoring methods have limited applicability and that multiple organism group approaches provide a more comprehensive ecological image of river health. The multiple organism group approach has gained considerable momentum in recent years, both in the U.S.A. (Barbour et al., 1999) and Europe, in particular since the implementation of the EU Water Framework Directive (O'Connor, Walls \& Hughes, 2000; Bryce et al., 2002; Hering, Johnson \& Buffagni, 2006b; Hering et al., 2006c; Johnson et al., 2006a; Johnson \& Hering, 2009). This approach assumes that different life history strategies of different communities will respond (in a measurable or quantifiable way through structural or functional changes in the community assemblage) to different types of stressors, providing complementary and comprehensive information on ecological status and pressures affecting the system (Hering et al., 2006c). Arguments against the multiple organism group approach include experimental design flaws, high costs, complicated logistics concerning implementation, potentially high levels of redundancy (i.e. fewer groups or even a single group can potentially provide relevant information on ecological status for management needs) and often inconclusive results (Resh, 2008).

Lotic biomonitoring programmes must be appropriate to river typology and based on biological indicators that respond to pressures in a way that is distinct from natural variation (Hering et al., 2006c). This means that suites of ecological indicators can vary between river types within a given ecoregion.
For example, Johnson et al. (2006a) found that fish, macroinvertebrates, macrophytes and benthic diatoms exhibited different degrees of response to stress gradients in European mountain and lowland streams. Mediterranean river typology is characterised by a predictable annual cycle of flood and drought that varies in intensity according to levels and duration of annual and interannual rainfall (Gasith \& Resh, 1999; Pires et al., 2004; Bêche \& Resh, 2007a,b; Bonada, Rieradevall \& Prat, 2007). This regime acts as an extremely strong environmental filter, shaping biological community traits (Poff, 1997; Statzner, Dolédec \& Hugueny, 2004; Bonada et al., 2005), a potential source of environmental covariance concerning biotic reactions to anthropogenic pressures. Iberia's Mediterranean rivers have a long history of human intervention including intensive agriculture and forestry, damming, abstraction and urbanisation, resulting in habitat fragmentation, soil erosion, reduced connectivity and disruption of natural flow regimes. These impacts compromise lotic structure and function in systems already subject to a harsh natural seasonal cycle of drought and flood (Aguiar \& Ferreira, 2005; Hooke, 2006; Hughes, Ferreira \& Cortes, 2008).

The incumbent Portuguese Government has authorised completion of a partially constructed dam on the Odelouca River by 2010 in order to augment and improve water supply in the Algarve region, but has demanded environmental mitigation and compensation measures to offset impacts caused during and after construction. The Odelouca, an intermittent Mediterranean river in the Algarve region of southern Portugal has been subject to human intervention along much of its catchment, but has high conservation value due to relatively intact and floristically unique riparian galleries found along stretches of the river corridor and the presence of two critically endangered endemic fish species (Santos \& Ferreira, 2008), the Iberian Chub Squalius aradensis (Coelho et al., 1998) and the Iberian nase Iberochondrostoma almacai (Coelho, Mesquita \& Collares-Pereira, 2005). 
This study aims to assess the structural and functional response of four organism groups (benthic macroinvertebrates, fish, birds and macrophytes) to environmental factors and pressures in an intermittent Mediterranean system and assess their suitability for future monitoring programmes and mitigation measures. In this study we have divided variables into (i) environmental variables, which essentially describe natural features such as valley form, altitude, the presence of depositional bars and $\mathrm{pH}$ and (ii) pressure variables describing types of impact such as changes in land use (agriculture, urbanisation) bankside disturbance and discharge into the watercourse. We also adopt the definition of structural (taxonomic composition and abundance) and functional composition (groups of metrics covering several properties of the communities under study) described by Feld \& Hering, 2007. Although metrics (i.e. functional data) are more commonly used for expressing ecological condition, changes in relative abundance can also provide important information on ecosystem patterns and may even contribute to the development of new metrics. A study of the effect of environmental stress on benthic macroinvertebrate assemblages in Central European lowland rivers found that levels of explained variance were higher for taxa (structure) than for metrics (function) (Feld \& Hering, 2007). We have investigated the relation of these organism groups to natural and stressor gradients in an intermittent Mediterranean river in order to compare the results of structural and functional data and assess candidate organism groups that best describe human induced change within the study area.

\section{Methods}

\section{Study area}

The Odelouca river $\left(511 \mathrm{~km}^{2}\right)$, a sub-catchment of the Arade basin $\left(987 \mathrm{~km}^{2}\right)$ is a medium-sized, low-gradient, lowland stream running through predominantly schistose areas characteristic of southern Portugal (Fig. 1). The climate is typically Mediterranean; mean monthly precipitation levels (Bravur a Reservoir, $15 \mathrm{~km}$ west of the study area) exemplify the seasonal rainfall pattern with a range of 59-102 $\mathrm{mm}$ from October 2004 to April 2005 and 2-38 mm from May to September 2005. Precipitation patterns result in a relatively slow running river subject to 'flashy' spates

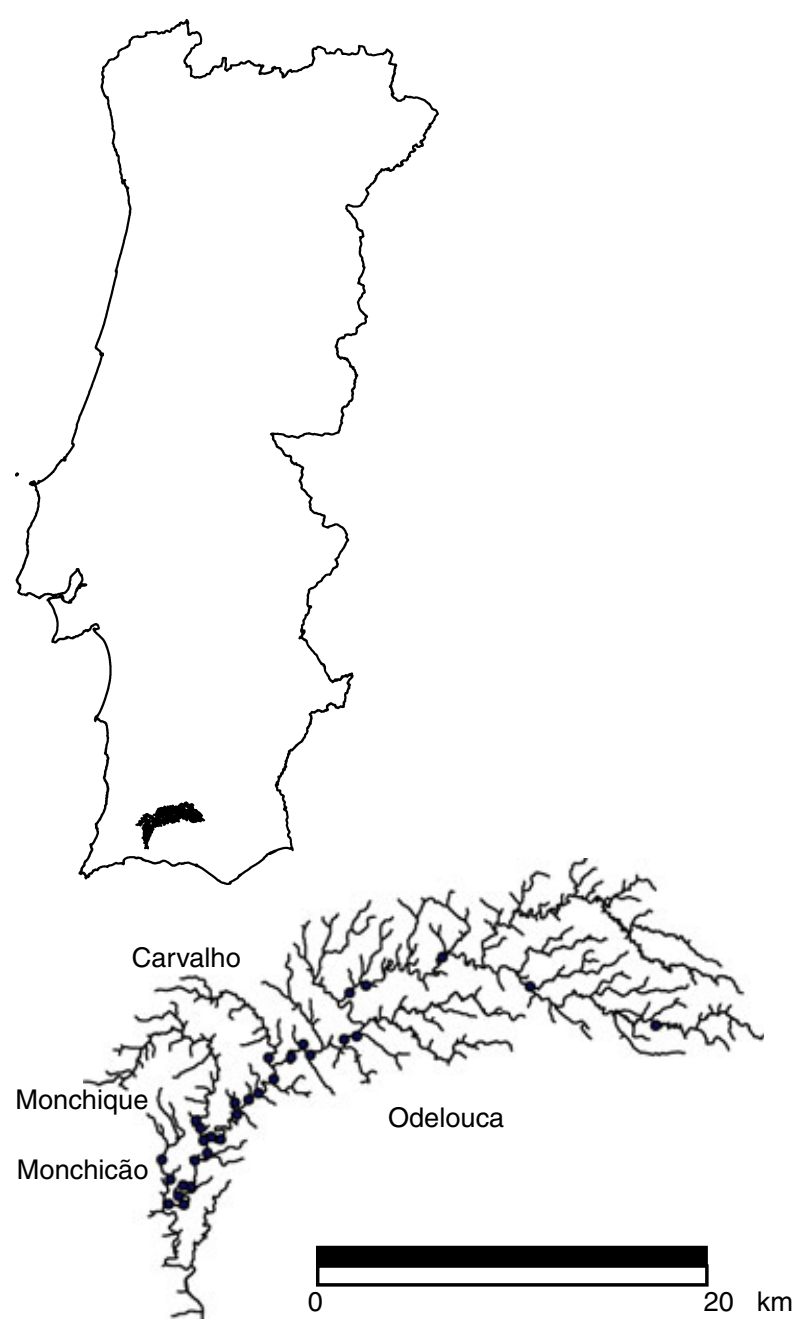

Fig. 1 Map of the Odelouca basin with sampling points.

in winter that dries to form unconnected, temporary pools (intermittent reaches sensu Gasith \& Resh, 1999) in the river bed during the summer.

Catchment topography varies from narrow steep sided valley walls to restricted meander valleys and small floodplains in the lower reaches. Temporary side channels, backwaters and dense riparian galleries occur in less disturbed mid sections and tributaries, which will be submerged following dam completion. Dominant woody riparian plants comprise Alnus glutinosa (L.) Gaertner, Salix salviifolia Brot. spp. australis Franco, Nerium oleander L, and Fraxinus angustifolia Vahl.. Stands of Tamarix africana Poiret and Nerium oleander L. occur along the drier lower reaches.

Agriculture (primarily extensive citrus groves) and grazing of goats and sheep have replaced the natural 
Mediterranean cork-oak (Quercus suber L.) woodland on the floodplain below the partially built dam (a cofferdam and an excavated subterranean flow diversion gallery). Observed impacts in the study area include diffuse organic pollution, nutrient enrichment, physical disturbance (riparian clearance, bank reinforcement) and reduced longitudinal connectivity (low-step damming and abstraction for irrigation by pumping from the riverbed). Urbanisation is relatively scant and Eucalyptus globulus Labill. and Pinus pinaster Aiton plantations are present in the higher areas of the basin. Tributaries suffer little physical disturbance, however the Monchique River receives organic input from piggeries and the small village of Monchique, whilst the lower reaches of the Monchicão tributary are affected by abstraction for agriculture. The Ribeira de Carvalho tributary is far less impacted.

\section{Field sampling and data collection}

Habitat assessment. Mediterranean systems are subject to flooding and drying (Gasith \& Resh, 1999), where a cycle of abiotic (scouring and drying) and biotic physicochemical factors (increased water temperature, and increased levels of predation in dry summer pools) exert a notable influence on river communities. Thus, all fieldwork was carried out between spring and early summer (February-May 2006), when full flow connectivity existed and levels of habitat diversity and available resources were highest. Data were collected from a total of 30 sites (Fig. 1): 25 sites along the main channel and five sites along the tributaries of Ribeira de Carvalho (1), Ribeira de Monchique (2) and the Ribeira de Monchicão (2).

Habitat structure, diversity and quality were assessed over a $500 \mathrm{~m}$ reach using an adapted version of the U.K. River Habitat Survey (RHS; addition of land use categories and plant species found on the Iberian Peninsula). RHS records substrata and flow type, natural features and modifications of the margins and river bed, land use, presence and complexity of riparian vegetation, together with measurements of stream and bank dimension (Raven et al., 1997). Features were recorded at 10 spot checks situated at $50 \mathrm{~m}$ intervals and then assessed over the whole $500 \mathrm{~m}$ stretch ('sweep up'). Recorded features were used to assess the extent of natural or artificial features and characterise river habitat condition.
Other important data on geology, climate, temperature, altitude, relief, land use, land cover, organic and industrial discharge and the presence of roads were obtained using GIS sources (the Portuguese National Water Institute - INAG, CORINE), aerial photography and downloadable catchment data from the INAG website (see Fernandes et al., 2007).

Lotic communities. All organism groups considered in this study were sampled within each $500 \mathrm{~m}$ RHS reach, using European STAR project methodologies (except for the avifauna), modified for application in Portuguese lotic systems (manuals published by INAG downloadable at http:/ /dqa.inag.pt/dqa2002/ port/docs_apoio/nacionais.html).

Benthic macroinvertebrate samples were taken along a $50-100 \mathrm{~m}$ long stretch at the beginning of each $500 \mathrm{~m}$ reach using an adapted AQEM multihabitat sampling protocol [AQEM, 1999; Hering et al., 2004; Instituto Nacional da Água (INAG), 2008a]. The sampling area was selected in order to cover the greatest possible diversity of habitats representative of the reach, including (if present) a riffle and areas of deposition. Types and extent of habitats were visually estimated and six 1-m long sampling units of the most representative habitats were taken $(0.25 \mathrm{~m} \times 0.25 \mathrm{~m}$ handnet; habitats with $<5 \%$ cover were excluded). The composite sample was placed in a labelled plastic flask and fixed in situ using $4 \%$ formaldehyde. In the laboratory, samples were washed, sieved, sorted and identified using a low-power stereo microscope. All individuals were picked from the samples; subsampling was used when more than 200 individuals of a given taxon were present in the sample. Macroinvertebrates were identified to the lowest possible taxonomic level, which was mostly genus or species. Where higher levels of taxonomic resolution were not possible (e.g. for many Diptera) the AQEM protocol for taxonomic adjustment was applied (Hering et al., 2002).

Fish were sampled using an adapted STAR methodology (INAG, 2008b) with an Electracatch International, SAREL model WFC7-HV electrofisher (applying $300 \mathrm{~V}$ and maintaining a 3-A output to a $40 \mathrm{~cm}$ stainless steel anode). Sampling was carried out (area sampled was 20 times the mean width of the survey reach, minimum length $100 \mathrm{~m}$ starting at RHS spot check 1) by walking upstream in a zig-zag pattern (Lyons, 1996) or sampling from a boat at sites 
over $1 \mathrm{~m}$ deep (Godinho, Ferreira \& Santos, 2000). Captured fish, held in large plastic containers, were identified to species, counted, and immediately returned to the river.

Bird surveys were carried out during the nesting period, ensuring the maximum number of nesting species, at three equidistant points $(250 \mathrm{~m}$ distance between points) including the riparian gallery and surrounding area (Bibby et al., 2000). All birds observed or heard were recorded over a 10-min period at each point. The distance of the bird from the observer was estimated when the distance was inferior to riparian gallery width. Birds were also surveyed on the flood plain c. $100 \mathrm{~m}$ perpendicular to each point in the riparian gallery. All recorded birds were identified to species.

Macrophyte inventories were carried out in spring and early summer when the greatest number of species was present and water transparency and depth were most favourable for survey work [Comité Européen de Normaliation (CEN), 2003] along $100 \mathrm{~m}$ reaches (at the start of the $500 \mathrm{~m}$ RHS reach), taking into account the percentage cover of each species in the sample area, evaluated as if observed macrophyte populations occurred as a single agglomeration (INAG, 2008c). Epiphytic bryophytes above the splashhumid zone were not included in the surveys. Species level determinations were made on site; specimens that could not be identified were taken to the Superior Agronomy Institute herbarium (Technical University of Lisbon) and bryophytes to the herbarium of the Botanical Garden (Science Faculty of Lisbon) for identification. A list of recorded taxa and metrics calculated for each group is given in Appendix S1.

At each macroinvertebrate and fish sampling site, physicochemical measurements of temperature, conductivity, $\mathrm{pH}$ and dissolved oxygen were taken with hand held electronic field probes. Depth was measured with a metre rule to the nearest centimetre and water velocity estimated with an ultrasonic flow meter (FP101 Global Flow Probe). Mean water velocity was measured at 0.6 total depth when total depth was $<0.8 \mathrm{~m}$; otherwise velocity was measured at 0.2 and 0.8 of total depth (Bovee \& Milhous, 1978).

Based on the literature and available data, a list of biological metrics was drawn up (Appendix S1a) covering, enumeration, diversity measures, tolerance/intolerance measures, habitat preference traits (e.g. zonation, habitat or flow preferences), feeding traits, mode of existence (e.g. locomotion) and taxonomic groups (see Feld \& Hering, 2007). Macroinvertebrate metrics were calculated using the ASTERISC software (version 3, downloaded from the AQEM website http:/ /www.aqem.de).

Data analyses. Redundant environmental and pressure parameters covering three spatial hierarchical levels (basin, reach and habitat) were removed using the Spearman Rank Correlation analysis method (Hering et al., 2006a,c; Feld \& Hering, 2007). If two environmental or pressure variables were highly correlated (threshold value of $r \geq 0.7$ ) the variable with a higher overall mean correlation coefficient was excluded from further analysis. A similar approach was used for the metrics calculated for each biological group (threshold of $r>0.8$ or $r<-0.8$ ). Considerable numbers of highly correlated variables and metrics still remained after this process, so it was repeated with a threshold of $r \geq 0.5$ or $r \leq-0.5$ for environmental and pressure variables and $r \geq 0.6$ or $r \leq-0.6$ for metrics.

Principal components analysis (PCA) was carried out on environmental and pressure data sets at each spatial level to reduce data dimensionality and identify the principal environmental and pressure gradients (May \& Brown, 2002). From an initial list of 38 environmental variables and 36 pressure variables, a total of 9 environmental and 10 pressure variables were retained (Table 1). The same procedure was carried out for functional data (metrics) for each organism group. A total of 22 metrics were retained from an initial list of 125 metrics (Appendix S1a) and a list of taxa for each organism group is given in Appendix S1b.

Structural and functional data for each organism group $[\log (x+1)$ or arcsin square root transformed according to data type; singly occurring specimens and those occurring at less than three sampling sites excluded] were analysed using detrended correspondence analysis (DCA) to assess the biological turnover or gradient within each data set and determine $a$ posteri use of unimodal or linear constrained response analyses (Gauch, 1982a). Gradient lengths obtained for all organism groups ( $<3.0 \mathrm{SD}$ units) indicated the use of a linear model. Manual forward selection using a cut off point of $P>0.1$ (Magnan \& Rodriguez, 1994; Griffith et al., 2003; Aguiar \& Ferreira, 2005) was used to retain non-redundant subsets of environmental and pressure variables explaining functional and structural data distribution patterns for each organism 
Table 1 Environmental (E) and pressure (P) variables divided over three spatial scales (basin, reach and habitat) retained for PCA and RDA after analysis for redundancy following comparison of the Spearman Correlation Coefficient

\begin{tabular}{|c|c|c|c|c|}
\hline \multicolumn{2}{|c|}{ Variable \& spatial scale } & Unitexpression & Abbreviation & Source of data \\
\hline \multicolumn{5}{|c|}{ Basin } \\
\hline $\mathrm{E}$ & Valley form & Class $0-4$ & VAL_FRM & GIS \\
\hline $\mathrm{P}$ & Urban area & $\%$ Catchment area & URB_A & GIS \\
\hline $\mathrm{P}$ & Monocultures & $\%$ Catchment area & MONO_A & GIS \\
\hline $\mathrm{P}$ & Agriculture & $\%$ Catchment area & AGRI_A & GIS \\
\hline \multicolumn{5}{|c|}{ Reach } \\
\hline E & Altitude & m.a.s.l & ALT & GIS \\
\hline E & Number of bars & Count & BARS & RHS \\
\hline E & Bankfull width (m) & Metres & BKFULL & RHS \\
\hline E & Average riparian width & Metres & WDTRIP & RHS \\
\hline E & Land use natura $V_{\text {semi-natural }}$ & Class $0-4(\%$ area $)$ & LU250_NAT & RHSGIS 250 m bankside buffer \\
\hline $\mathrm{P}$ & Bank reinforced & Count derived score $0-4$ & BK_RI & RHS \\
\hline $\mathrm{P}$ & Bank embanked & Count derived score $0-4$ & BK_EM & RHS \\
\hline $\mathrm{P}$ & Land use agriculture & Class $0-4(\%$ area $)$ & LU250_AG & RHS/GIS 250 m bankside buffer \\
\hline \multicolumn{5}{|c|}{ Habitat } \\
\hline E & $\mathrm{pH}$ & Sorensen scale & PH & Sample site \\
\hline $\mathrm{E}$ & Dissolved oxygen & $\mathrm{mg} \mathrm{L}^{-1}$ & $\mathrm{DO}$ & Sample site \\
\hline $\mathrm{E}$ & Water velocity & $\mathrm{m} \mathrm{s}^{-1}$ & WVEL & Sample site \\
\hline $\mathrm{P}$ & Bank modification & & BNK_MOD & RHS/sample site \\
\hline $\mathrm{P}$ & Channel modification & & CH_MOD & RHS/sample site \\
\hline $\mathrm{P}$ & Banktop landuse agriculture & Class & BT_AG10 & RHS/sample site $10 \mathrm{~m}$ bnkside buffer \\
\hline $\mathrm{P}$ & Banktop landuse pasture & Class & BT_RP10 & RHS/sample site $10 \mathrm{~m}$ bnkside buffer \\
\hline
\end{tabular}

group. RDA was carried out on selected environmental and pressure variables for the functional and structural data of each organism group. A MonteCarlo permutation test ( 999 permutations) on the first axis eigenvalue and the sum of all canonical eigenvalues or 'trace' evaluated the significance of the environmental and pressure effects for each analysis. To further aid interpretation of results, Spearman rank correlations $(P<0.05)$ were calculated between retained organism group metricstaxa (explained variance values $\geq 15 \%$ ) and the samples scores of RDA ordination axes 1 and 2 (where most of the variance tends to reside). CANOCO 4.5 (ter Braak \& Smilauer, 1998) was used for DCA and RDA analyses and Statistica (version 6.0, Statsoft, Tulsa, OK, U.S.A.) for the calculation of correlation coefficients. For clarity, only taxa and metrics with explained variance values $\geq 15 \%$ are shown in the ordination plots (Feld \& Hering, 2007).

\section{Results}

\section{Environmental and pressure gradients}

PCA indicated higher levels of explained variance at the highest and lowest spatial scales, followed by
Table 2 PCA eigenvalues and loadings (axes 1 and 2) for retained environmental and pressure variables divided over three spatial scales of habitat, reach and basin. Only variables with loadings $\geq 0.5$ on at least one of the first two PC axes are listed

\begin{tabular}{|c|c|c|c|c|c|}
\hline \multicolumn{3}{|l|}{ Environment } & \multicolumn{3}{|l|}{ Pressures } \\
\hline & Axis 1 & Axis 2 & & Axis 1 & Axis 2 \\
\hline \multicolumn{6}{|l|}{ Basin } \\
\hline Eigenvalue & 0.726 & 0.274 & Eigenvalue & 0.539 & 0.332 \\
\hline \multirow[t]{3}{*}{ VAL_FRM } & 1 & 0.004 & URB_A & -0.626 & 0.049 \\
\hline & & & MONO_A & -0.963 & 0.189 \\
\hline & & & AGRI_A & -0.281 & -0.959 \\
\hline \multicolumn{6}{|l|}{ Reach } \\
\hline Eigenvalue & 0.393 & 0.252 & Eigenvalue & 0.329 & 0.244 \\
\hline ALT & -0.712 & 0.650 & BK_RI & 0.511 & -0.376 \\
\hline BARS & 0.655 & 0.613 & BK_EM & 0.845 & 0.503 \\
\hline WDTRIP & -0.772 & 0.013 & LU250_AG & 0.427 & -0.7675 \\
\hline LU250_NAT & -0.526 & 0.241 & & & \\
\hline \multicolumn{6}{|c|}{ Habitat } \\
\hline Eigenvalue & 0.518 & 0.348 & Eigenvalue & 0.444 & 0.315 \\
\hline WVEL & -0.749 & -0.660 & BNK_MOD & 0.659 & 0.713 \\
\hline $\mathrm{pH}$ & -0.800 & 0.599 & CH_MOD & 0.062 & 0.574 \\
\hline \multirow[t]{2}{*}{$\mathrm{DO}$} & -0.539 & 0.016 & BT_AG10 & -0.068 & 0.578 \\
\hline & & & BT_RP10 & 0.888 & -0.427 \\
\hline
\end{tabular}

reach scale for both sets of variables (see Table 1 for details of retained variables and abbreviations and Table 2 for PCA results). For clarity, only variables with loadings $\geq 0.5$ are described. The first two axes 
of the basin level environmental PCA explained 100\% of the variance (axis $1=72.6 \%$, axis $2=27.4 \%$ ), separating tributary sites and headwater sites situated in deep vee valleys from more heterogeneous mid section sites and shallow vee valley sites downstream of the cofferdam. The first two axes of reach level environmental variables $(n=4$; loadings $\geq 0.5)$ explained $64.5 \%$ of the variance (axis $1=39.3 \%$, axis $2=25.2 \%$ ), separating sites with lower levels of human intervention situated higher up the river corridor from those below the cofferdam. Higher lying sites were characterised by riparian galleries, natural adjacent land use and instream habitat heterogeneity (the presence of bars). Habitat level PC axes explained $86.6 \%$ of the variance (axis $1=52.8 \%$, axis $2=34.8 \%$ ); the highest loadings along axes 1 and 2 were water velocity (WVEL, -0.749 and -0.660 respectively) and $\mathrm{pH}(\mathrm{PH},-0.800$ and 0.599 respectively). Habitats in the middle and upper reaches were characterised by higher water velocity levels (WVEL), while lower lying sites had higher $\mathrm{pH}$, temperature and dissolved oxygen levels (DO). Higher dissolved oxygen and to some extent even $\mathrm{pH}$ levels can be attributed to the considerable daytime photosynthetic activity of dense stands of macrophytes and filamentous algae recorded at lower sites.

Basin level PC analysis of pressures (total explained variance $87.1 \%$; axis $153.9 \%$, axis $2=33.2 \%$ ) illustrated the effect of large scale changes in land use, attributed primarily to agriculture (MONO_A and AGRI_A). The first two axes of the reach level pressure PCA explained $57.3 \%$ of the variance. Loadings ( $\geq 0.5$ ) along axis 1 clearly described physical bankside disturbance (BK_RI and BK_EM) and changes in adjacent land use (LU250_AG), mostly at sites on the floodplain below the cofferdam. Habitat level PCA (axes 1 and 2 explained $75.9 \%$ of the variance) indicated variables (loadings $\geq 0.5$ ) describing physical disturbance including bankfacetop and the river channel modification and agricultural and pastoral activities (grazing at the banktop).

\section{Forward selection of variables}

Forward selection created non-redundant subsets of variables describing higher levels of variance in relation organism group structure and function

Table 3 Results of the manual forward selection procedure of environmental and pressure variables relative to the functional (F) and structural (S) data for each organism group (spatial scale: $\mathrm{B}=$ basin, $\mathrm{R}=$ reach, $\mathrm{H}=$ habitat)

\begin{tabular}{|c|c|c|c|c|c|c|c|c|c|c|}
\hline \multirow{2}{*}{\multicolumn{2}{|c|}{$\begin{array}{l}\text { Feature and corresponding } \\
\text { spatial scale }\end{array}$}} & \multicolumn{2}{|c|}{$\begin{array}{l}\text { Inverte- } \\
\text { brates }\end{array}$} & \multicolumn{2}{|c|}{ Fish } & \multicolumn{2}{|c|}{ Birds } & \multicolumn{2}{|c|}{$\begin{array}{l}\text { Macro- } \\
\text { phytes }\end{array}$} & \multirow[b]{2}{*}{$\sum$} \\
\hline & & $\mathrm{F}$ & $S$ & $\mathrm{~F}$ & $\mathrm{~S}$ & $\mathrm{~F}$ & $\mathrm{~S}$ & $\mathrm{~F}$ & $\mathrm{~S}$ & \\
\hline \multicolumn{11}{|c|}{ Environmental variables } \\
\hline $\mathrm{PH}$ & $\mathrm{H}$ & & $\bullet$ & $\bullet$ & $\bullet$ & $\bullet$ & $\bullet$ & & $\bullet$ & 6 \\
\hline ALT & $\mathrm{R}$ & & $\bullet$ & $\bullet$ & $\bullet$ & $\bullet$ & $\bullet$ & & & 5 \\
\hline WVEL & $\mathrm{H}$ & $\bullet$ & $\bullet$ & & & & & & $\bullet$ & 3 \\
\hline BARS & $\mathrm{R}$ & & & - & $\bullet$ & & & & & 2 \\
\hline WDTRIP & $\mathrm{R}$ & & & & $\bullet$ & & & & & 1 \\
\hline LU250_NAT & $\mathrm{R}$ & & & & & $\bullet$ & & & & 1 \\
\hline VAL_FRM & $\mathrm{B}$ & & & & & $\bullet$ & & & & 1 \\
\hline$\sum \mathrm{F} S$ & & 1 & 3 & 3 & 4 & 4 & 2 & 0 & 2 & \\
\hline$\sum$ organism group & & 4 & & 7 & & 6 & & 2 & & \\
\hline \multicolumn{11}{|l|}{ Pressure variables } \\
\hline LU250_AG & $\mathrm{R}$ & & $\bullet$ & & & & $\bullet$ & & $\bullet$ & 3 \\
\hline CH_MOD & $\mathrm{H}$ & & & $\bullet$ & $\bullet$ & & & & & 2 \\
\hline BK_RI & $\mathrm{R}$ & & & & & $\bullet$ & $\bullet$ & & & 2 \\
\hline BT_AG10 & $\mathrm{H}$ & & & & & $\bullet$ & & & & 1 \\
\hline BNK_MOD & $\mathrm{H}$ & & & & & & & $\bullet$ & & 1 \\
\hline MONO_A & $\mathrm{B}$ & & & & & & & & $\bullet$ & 1 \\
\hline$\sum \mathrm{F} S$ & & 0 & 1 & 1 & 1 & 2 & 2 & 1 & 2 & \\
\hline $\bar{\sum}$ organism group & & 1 & & 2 & & 4 & & 3 & & \\
\hline $\begin{array}{l}\text { Overall total per } \\
\text { organism group }\end{array}$ & & 1 & 4 & 4 & 5 & 6 & 4 & 1 & 4 & \\
\hline
\end{tabular}


(Table 3). The number of variables shared between organism groups ranged from two to six; five selected variables were unique to the structural or functional data of a particular organism group.

The variables $\mathrm{pH}(\mathrm{PH})$ and altitude (ALT) were highly redundant between all four organism groups. Forward selection retained more environmental variables than pressure variables for all organism groups, except macrophytes (environmental variables $n=2$, pressure variables $n=3$ ). A maximum of seven environmental variables were retained for fish, followed by six for birds, four for macroinvertebrates and only two (structural data) for macrophytes. More environmental variables were retained for organism group structural data, with the exception of avian data. Intra group redundancy was highest within the fish for $\mathrm{pH}(\mathrm{PH})$, altitude (ALT) and the presence of bars (BARS) and inter group redundancy was highest between fish and bird structural and functional data ( $\mathrm{pH}$ and altitude). Fewer pressure variables were retained across the organism groups and intra group and inter group redundancy levels were lower. However, LU250_AG, indicating agricultural land use was selected for macroinvertebrate, avian and macrophyte structural data. Intra group redundancy was evident for channel and bankside disturbance (CH_MOD and BK_RI) for fish and bird groups. The highest number of retained pressure variables $(n=4)$ was for birds followed by macrophytes $(n=3)$. A single variable was retained for benthic macro- invertebrate structural data and none for functional data indicating that the selected metrics do not appear to reflect the principal detected pressures.

Most retained variables derived from reach scale $(46.15 \%)$, followed by habitat $(38.46 \%)$ and basin level $(15.37 \%)$. Similar to Feld \& Hering (2007), the larger number of selected reach level variables may highlight the importance of processes at this spatial scale in determining group structure and function or the pervasive effect of predominantly reach level RHS recorded variables in the dataset.

\section{$R D A$ results}

The extracted first axis and trace for RDA ordinations were mostly highly significant (Monte Carlo test; Table 4), with the exception of benthic macroinvertebrate and macrophyte functional data. Fish and bird structural and functional data provided the highest axis 1 eigenvalues. RDA ordination plots revealed the relation between organism groups and retained variables (Figs $2 \& 3$ ).

Water velocity (WVEL) was the only variable retained for the macroinvertebrate functional RDA (Fig. 2a). Metrics ( $>15 \%$ explained variance) were negatively correlated with axis 1 , indicating the presence of organisms with rheophilic current preferences (\%_RHEOPHIL, $r=-0.812)$, lithal microhabitat preferences ( $\%$ LITHAL, $r=-0.661$ ), higher numbers of Trichoptera taxa (N_TRICH, $r=-0.866$ ) and EPT

Table 4 Results of RDA and Monte Carlo permutations ( $F$ statistic, 999 permutations) for testing the significance of environmental and pressure variables retained by forward selection in relation to structural and functional data of benthic macroinvertebrates, fish, birds and macrophytes

\begin{tabular}{|c|c|c|c|c|c|c|c|c|}
\hline & \multicolumn{5}{|c|}{ 1st canonical axis } & \multicolumn{3}{|c|}{ Sum of all canonical axes (trace) } \\
\hline & \multicolumn{3}{|c|}{ Eigenvalue axes 1-3 } & $F$ ratio 1 st axis & $P$ 1st axis & Eigenvalue & $F$ ratio all axes & $P$ all axes \\
\hline \multicolumn{9}{|c|}{ Invertebrates } \\
\hline $\mathrm{F}$ & 0.078 & 0.741 & 0.098 & - & - & 0.078 & 2.382 & $0.054 \mathrm{~ns}$ \\
\hline S & 0.215 & 0.067 & 0.038 & 6.867 & $0.001^{* * *}$ & 0.353 & 3.406 & $0.001^{* * *}$ \\
\hline \multicolumn{9}{|l|}{ Fish } \\
\hline $\mathrm{F}$ & 0.304 & 0.138 & 0.028 & 10.493 & $0.001^{* * *}$ & 0.472 & 5.356 & $0.001^{* * *}$ \\
\hline$S$ & 0.199 & 0.179 & 0.064 & 5.731 & $0.009^{* *}$ & 0.466 & 4.018 & $0.001^{* * *}$ \\
\hline \multicolumn{9}{|c|}{ Birds } \\
\hline $\mathrm{F}$ & 0.312 & 0.154 & 0.043 & 10.447 & $0.004^{* *}$ & 0.515 & 4.072 & $0.001^{* * *}$ \\
\hline$S$ & 0.166 & 0.064 & 0.039 & 4.971 & $0.001^{* * *}$ & 0.284 & 2.476 & $0.001^{* * *}$ \\
\hline \multicolumn{9}{|c|}{ Macrophytes } \\
\hline $\mathrm{F}$ & 0.083 & 0.443 & 0.313 & - & - & 0.083 & 2.537 & $0.061 \mathrm{~ns}$ \\
\hline S & 0.157 & 0.077 & 0.049 & 4.665 & $0.001^{* * *}$ & 0.303 & 2.712 & $0.001^{* * *}$ \\
\hline
\end{tabular}

F, function; S, structure; ns, not significant.

${ }^{* *} P<0.01 ; * * P<0.001$. 
(a)

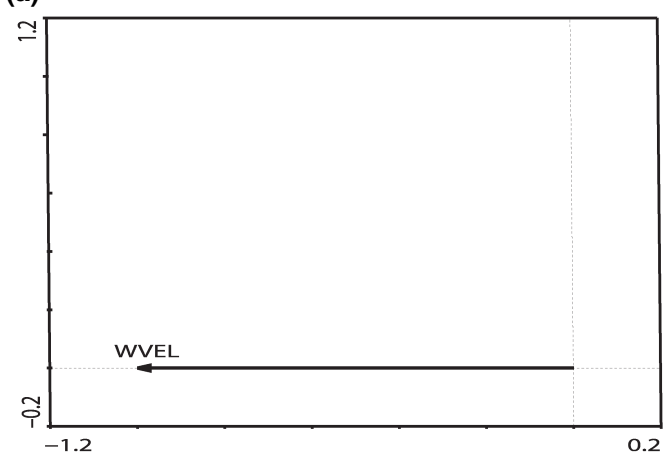

(b)

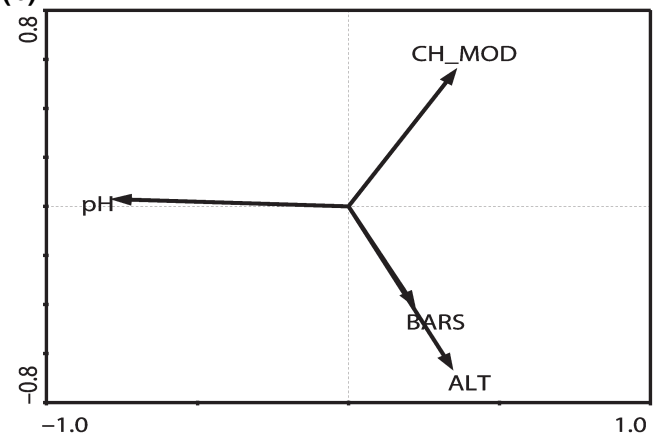

(c)

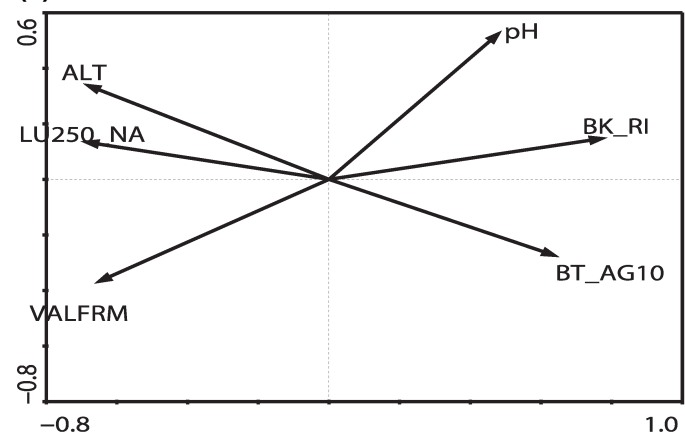

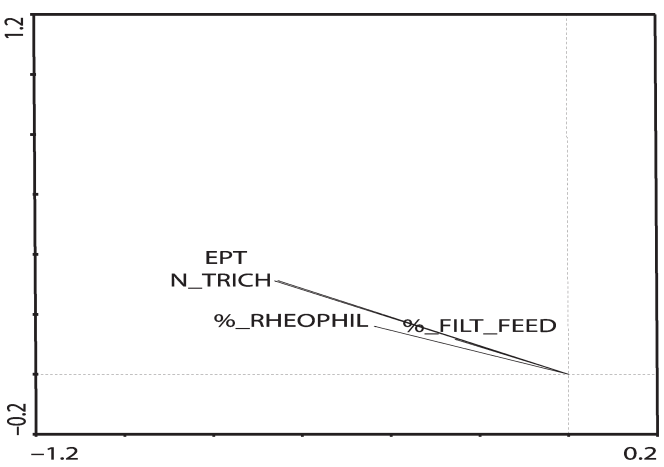
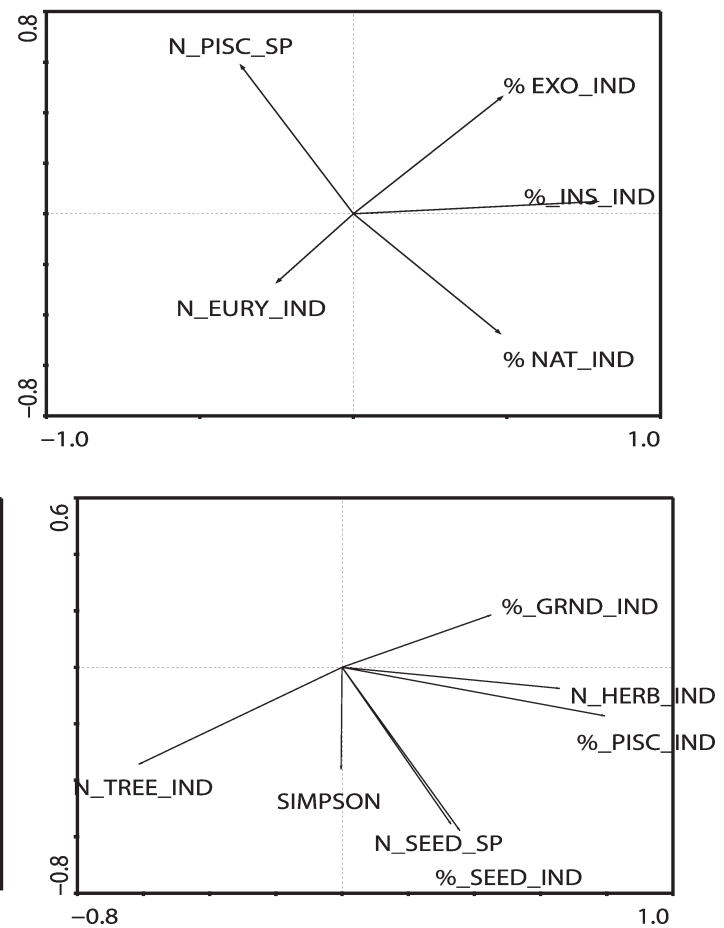

Fig. 2 RDA ordination plots of environmental and pressure variables and (a) macroinvertebrate functional data, (b) fish functional data and (c) bird functional data. Only functional organism group descriptors with $>15 \%$ explained variance are shown (no macrophyte functional descriptors explained $>15 \%$ variance). Biplots in the left hand column describe environmental and pressure variable distribution in the ordination space with those in the right hand column describe the distribution of metrics in the ordination space.

(Ephemeroptera, Plecoptera and Trichoptera) taxa (EPT, $r=-0.821)$. Despite initial sorting using the Spearman Rank Correlation (see Hering et al., 2006a,c; Feld \& Hering, 2007), the proximity of the metrics in the ordination space suggests collinearity.

The taxa based RDA (Fig. 3a) indicated strong environmentalpressure gradients along axes 1 and 2, illustrated by the length of the arrows attributed to the ordinated variables. Axis 1 revealed a longitudinal $\mathrm{pH}$ (intra-set correlation $r=-0.889$ ) and altitude gradient (intra-set correlation $r=0 \quad 0.586$ ), essentially representing the river continuum. Axis two separated faster flowing sites (WVEL, intra-set correlation $r=-0.454$ ) from slow flowing sites in areas affected by agricultural land use (LU250_AGR intra-set correlation -0.869). A longitudinal taxonomic distribution pattern showed that taxa occurring more abundantly in the lower reaches of the Odelouca (higher $\mathrm{pH}$ axis 1) included Baëtis sp. $(r=-0.831)$, Chironomidae $(r=-0.831)$, Dugesia sp. $(r=-0.764)$, Gyraulus sp. 
(a)

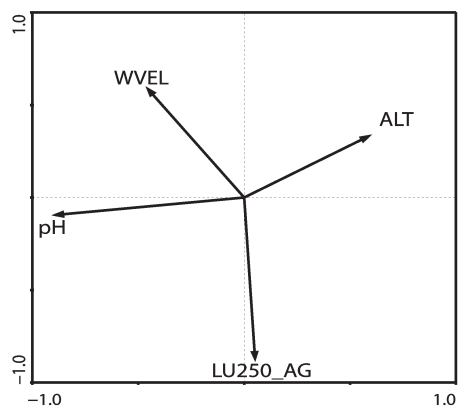

(b)

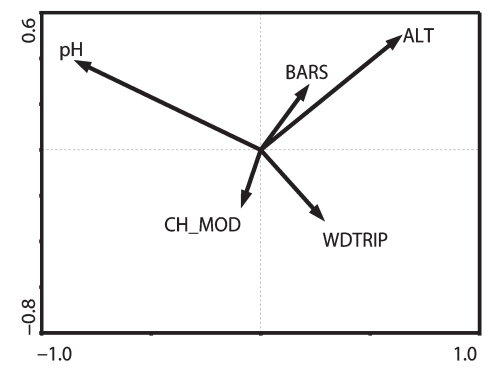

(c)

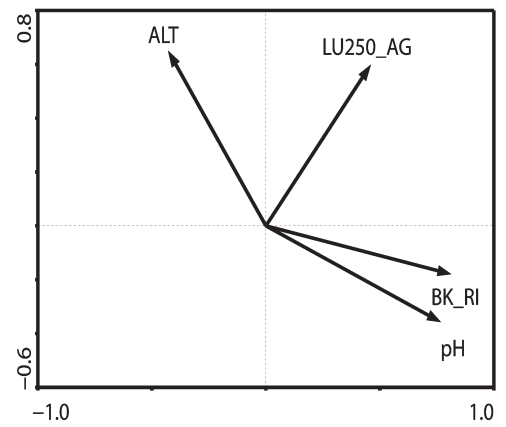

(d)

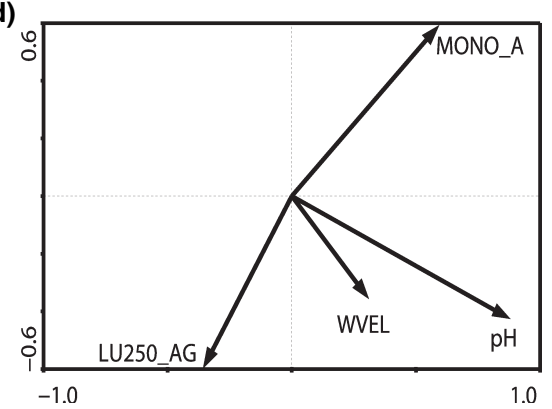

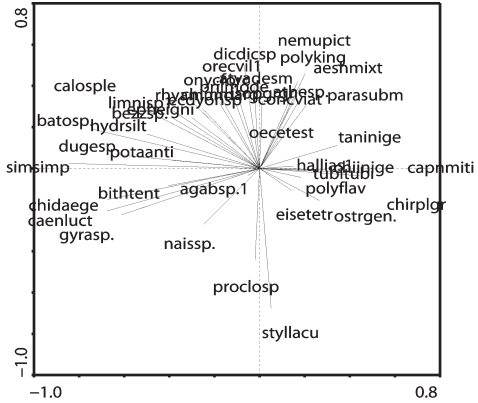
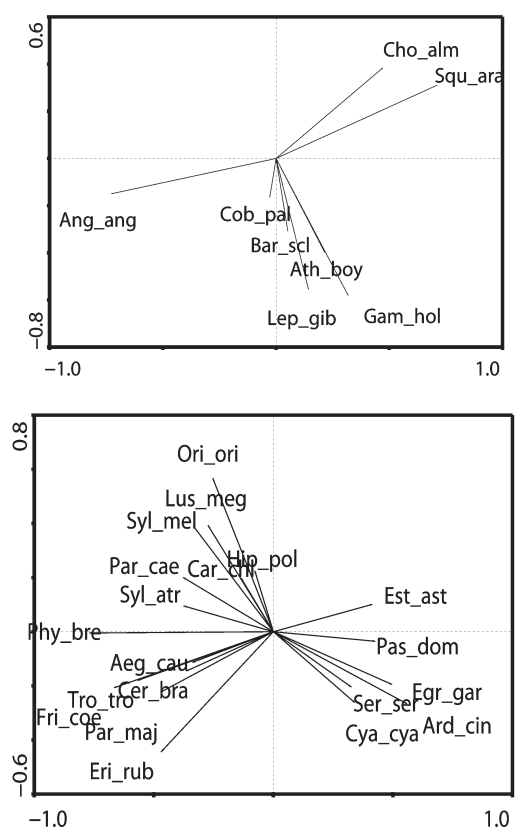

$-1.0$

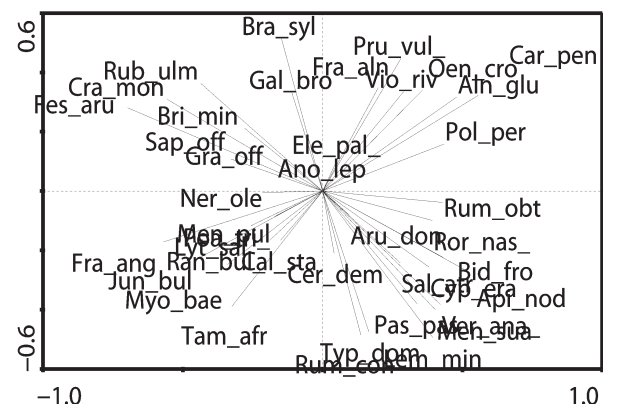

Fig. 3 RDA ordination plots of environmental and pressure variables and (a) macroinvertebrate structural data, (b) fish structural data (c) bird structural data (d) macrophyte structural data. Only structural organism group descriptors with an explained variance $>15 \%$ are shown. Biplots in the left hand column describe environmental and pressure variable distribution in the ordination space with those in the right hand column describe the distribution of taxa in the ordination space.

$(r=-0.0 .688)$ and Simulium sp. $(r=-0.849)$. Taxa at the other end of this gradient were Capnioneura mitis Despax $(r=0.469)$, Tanytarsini, and Chironomus plumosus-gr (both not significant). Stylaria lacustris L. $(r=-0.822)$ and Procloeon sp. $(r=-0.577)$ were strongly associated with the agricultural land use (axis 2), while Dicronata sp. $(r=0.680)$, Atherix sp. $(r=0.670)$ and Onychogomphus forcipatus L. $(r=0.653)$ were associated with higher water velocity.

Axis 1, revealed as a longitudinal $\mathrm{pH}$ gradient (intraset correlation $r=-0.765$ ), was also evident for fish functional data (Fig. 2b), while axis 2 represented 
changes in instream properties from less disturbed higher reaches (ALT intra-set correlation -0.650, BARS intra-set correlation -0.394) to lower lying reaches affected by channel modification (CH_MOD intraset correlation 0.546). Fish metrics clearly separated sites along this gradient, describing shifts in exotic or native species status and feeding or habitat preferences. No diversity indices were selected, a facet of the harsh Mediterranean intermittent habitat templet resulting in depauperate fish assemblages (Magalhães et al., 2002). The percentage of insectivore fish species $(r=0.969)$ clearly separated sites along axis 1 , while metrics describing percent exotic and native individuals reflected physical habitat change $(r=0.666$ and $r=-0.868$ respectively). Piscivorous species were negatively associated with less disturbed sites.

Patterns in fish structural data closely mirrored metric distribution patterns, since metrics were derived from a small number of ecologically distinct species (Fig. 3b). Axis 1 also described a longitudinal $\mathrm{pH}$ gradient, while axis 2 described a shorter gradient related to channel modification and riparian gallery width (intraset correlation CH_MOD $=-0.228$, WDTRIP $=-0.292$ ). Threatened native species were clearly associated with instream habitat quality and negatively associated with downstream habitat degradation (axis 1: S. aradensis, $r=0.763$, I. almacai, $r=0.51$; axis 2 : S. aradensis, $r=0.533$, I. almacai, $r=0.413$ ). Although widespread, the eel Anguilla anguilla L. was more abundant at lower lying sites (axis 1, $r=-0.770$ ). A mixture of exotic (Gambusia holbrooki Girard and Lepomis gibbosus L.) and native (Atherina boyeri Risso, Barbus sclateri Günther and Cobitis paludica de Buen) species were associated with channel modification and riparian width. The presence of the native Iberian barbel, $B$. sclateri reflected its preference for pool-like conditions (Magalhães et al., 2002) within the vicinity of the cofferdam, while the exotic G. holbrooki comprised just over $50 \%$ of the total catch at sites close to the cofferdam, where flow conditions were much reduced but riparian galleries were still present.

Bird functional data (Fig. 2c) strongly separated sites along distinct environmental and pressure gradients (axis 1) related to land use and bankside physical impacts. Most retained metrics described either feeding or habitat preferences; only a single diversity index (Simpson) was retained. Parameters on the left side of the biplot (Fig. 2c) separated higher lying sites with natural land use situated in asymmetrical or narrower valleys (intraset correlatons $\mathrm{ALT}=-0.681, \quad \mathrm{LU} 250 \mathrm{NAT}=-0.685, \quad$ VALFRM $=$ -0.649 ) with good riparian stands, reflected in the metric describing the number of tree dwelling individuals (N_TREE_IND). Parameters on right side of the biplot separated lower lying sites subject to physical impacts such as bank reinforcement (intraset correlation BK_RI $=0.771$ and BT_AG10 $=0.636$ ). Associated metrics included the number of herbivore individuals (N_HERB_IND, $r=0.564$ ) and the percentage of piscivorous individuals (\%_PISC_IND, $r=0.672$ ). Metrics describing seed eating species and individuals along axis 2 tended to be higher in areas affected by agriculture (N_SEED_SP, $r=-0.789$; $\%$ _SEED_IND, $r=-0.659$ ), reflecting a change in vegetation resulting from riparian clearance and the natural presence of more open ground. The number of tree dwelling individuals was highly correlated with both axes 1 and 2 (N_TREE_IND, axis $1, r=-0.692$, axis $2, r=-0.585)$.

Avian structural data revealed distinct groups of species (Fig. 3c). The longitudinal gradient from higher lying sites to lower lying degraded sites was discernible (axis 1 intraset correlation: $\mathrm{pH}, r=0.750$, BK_RI, $r=0.794$; axis 2 intraset correlation: ALT, $r=0.633$, LU250_AG, $r=0.582)$. Species clearly associated with bankside disturbance (reinforcement) at lower lying sites were the Grey Heron Ardea cinerea L. (axis 1, $r=0.452$ ), the little Egret Egretta garzetta L. (axis 1, $r=0.557$ ) and the house sparrow Passer domesticus L. (axis $1, r=0.557$ ). Woodland species negatively associated with agricultural areas were the Iberian Chiffchaff Phylloscopus brehmii von Homeyer, the chaffinch Fringilla coelobs L. (axis 1, $r=-0.706$ ), the Great Tit Parus major L. (axis $1, r=-0.516$ ) and the Northern Wren Troglodytes troglodytes L. (axis 1, $r=-0.825)$. A third group of predominantly woodland/scrub species was also associated with less impacted sites situated further upstream. Species significantly correlated with axis 2 were the Nightingale Luscinia megarhynchos Brehm (axis 3, $r=0.641$ ), the golden Oriole Oriolus oriolus L. (axis 2, $r=0.781$ ) and the Sardinian Warbler Sylvia melanocephala Gmelin (1axis, $r=0.518$ ).

No macrophyte metric explained more than $15 \%$ variance relative to the single retained pressure variable describing bank modification, hence no figure is given. Macrophyte structural data revealed distinct 
distribution patterns related to longitudinal changes in the hydric regime and habitat degradation associated with land use (Fig. 3d). The longitudinal $\mathrm{pH}$ gradient ( $\mathrm{pH}$, axis 1 intraset correlation, $\mathrm{r}=0.859$; axis 2 , intraset correlation, $r=-0.416$ ) and land use gradient was evident (LU250_AG, axis 1 intraset correlation, $r=0.344$; axis 2, intraset correlation, $r=-0.576$; MONO_A, axis 1 intraset correlation, $r=0.576$; axis 2 intraset correlation, $r=0.576$ ). Woody riparian species tolerant of wetter conditions, such as the common alder Alnus glutinosa (L.) Gaertner (axis 1, $r=0.577$; axis 2, $r=0.484$ ), the glossy Buckthorn Fraxinus alnus P. Mill (axis 2, $r=0.495$ ), the dog violet Viola riviniana (Rchb.) and Common Selfheal Prunella vulgaris L. subspecies vulgaris (axis 2, $r=0.450$ ), were associated with tributary sites where narrow strips of monocultural cereal crops (MONO_A) were present beyond the riparian zone. Woody shrubs tolerant of arid and disturbed conditions such as Tamarix africana Poiret (axis 1, $r=0.368$; axis 2, $r=0.663$ ) the Desert or Narrow Leaved Ash Fraxinus angustifolia Vahl. (axis 1, $r=-0.804$ ) and Juncus bulbosus L. (axis 1, $r=-0.514$ ) were present at sites affected by agriculture. Degraded lower lying sites were characterised by the instream presence of false water cress Apium nodiflorum (L.) (axis 1, $r=0.671$ ) and Common Duckweed Lemna minor L. (axis 2, $r=-0.505$ ) and common tickseed Bidens frondosa L. (axis 1, $r=0.766$ ), Cyperus eragrostis Lam (axis 2, r =-0405) on the bankside. Species at main channel sites with lower levels of human intervention included woody shrub species such as the bramble Rubus ulmifolius Scott (axis 1, $r=-0.618$ ), the common Hawthorn Crataegus monogyna Jacq (axis $1, r=-0.509$ ) and Festuca arundinacea Schreber (axis $1, r=-0.749$ ).

\section{Discussion}

The Habitat Templet Theory (Southwood, 1977, 1988) describes organism structural and functional traits as a reflection of contemporary habitat conditions. Integrated multiple organism approaches use responses from a range of different life histories under certain habitat conditions to provide an early warning system to particular pressures with hopefully little or no redundancy (Furse et al., 2006; Hering et al., 2006b). Ideally, organism group response to stressors should be type specific and easily distinguishable from responses to environmental gradients (Johnson et al., 2006a). The results of this study highlight important considerations in selecting suitable indicator organism groups for effective biomonitoring programmes, such as river typology, the identification of environmental gradients, the types of impact affecting the system under study and links between organism groups and stressors (Hering et al., 2006a,c; Resh, 2008).

PCA revealed scale dependent environmental and pressure factors and potentially high levels of covariance (Frissell et al., 1986; Allan, Erickson \& Fay, 1997; Allan \& Johnson, 1997; Poff, 1997; Hawkins et al., 2000 Allan, 2004). European Mediterranean river basins have a long history of human disturbance from changes in land use on the floodplain to management of the channel and riverbanks for flood protection and to increase water supply. The history of human activity in Iberian Mediterranean systems, combined with the natural temporal and spatial fluvial patterns in these systems (Gasith \& Resh, 1999) obscures the ready distinction of these two sources of variability (Hooke, 2006; Díaz, Suárez Alonso \& Vida-Abarca Gutiérrez, 2008).

A purported advantage of the multi organism approach is that the range of responses distinguishes different types of stressors that are ideally distinct from responses to natural phenomena. Redundancy analysis clearly showed environmental factors to be major drivers of change in group structure and function, directly and indirectly describing essentially longitudinal distribution patterns, resulting in high levels of intra and intergroup redundancy for parameters such as $\mathrm{pH}$ and altitude. Ostensibly classified as an environmental factor in this study, the chemical $\mathrm{pH}$ gradient illustrates the combined effect of multiple mechanisms operating over several spatial scales as a result of underlying natural biotic and abiotic gradients, changes in land use and enrichment. Background $\mathrm{pH}$ levels are normally determined by catchment geology and biotic processes such as decomposition, photosynthesis and respiration (Townsend, Hildrew \& Francis, 1989). Less shaded lower reaches of the Odelouca (increased bankfull width, riparian clearance and changes in land use) were characterised by dense aquatic macrophyte stands of false water cress Apium nodiflorum (L.), Potamogeton and filamentous algae (recorded using RHS). Higher $\mathrm{pH}$ levels were almost certainly partly attributable to increased runoff and photosynthetic activity which influenced instream physicochemical 
processes. A prior study on $\mathrm{pH}$ gradients and land use in Southern English streams has described the reason for the strong $\mathrm{pH}$ gradient and its obvious influence upon macroinvertebrate community structure as 'undoubtedly complex' (Townsend et al., 1989).

Retained pressure variables described changes in land use or physical disturbance of the bankside or channel. The number of pressure variables retained and levels of redundancy were lower and it became clear that benthic macroinvertebrate and macrophyte based metrics were not reliable indicators of the physical sources of disturbance recorded in the study area. By contrast, Feio et al. (2007) found macroinvertebrate assemblages in the Mondego River, a transitional river system in central Portugal, to be sensitive to morphological bankside and channel disturbance. These different responses are almost certainly related to typology. The Mondego is a predominantly perennial river system compared to the highly intermittent Mediterranean character of the Odelouca, where benthic macroinvertebrate communities are naturally tolerant of periods of physical disturbance such as scouring caused by winter rainfall runoff followed by drought. Hering et al. (2006b) consider benthic macroinvertebrate communities to be unsuitable for monitoring hydromorphological degradation in southern European rivers due to the lack of taxonomical knowledge. However, macroinvertebrate structural distribution patterns were clearly related to large scale changes in land use and water velocity, a vital environmental variable that will be drastically altered upon completion of the Odelouca dam.

Mediterranean flow patterns strongly affect macroinvertebrate communities; water velocity was shown to be an important environmental variable for benthic macroinvertebrate structure and function in this study. Marked shifts in benthic macroinvertebrate taxonomic and biological traits, community structure and abundance have been found in long term studies of wet and dry years in intermittent Mediterranean systems (Bêche, McElravy \& Resh, 2006; Bêche \& Resh, 2007b; Bonada et al., 2007) and in Mediterranean systems with permanent, intermittent and ephemeral flow regimes (Bonada et al., 2007). Bonada et al. (2007) also found a predominance of invertebrate taxa with pool like strategies in intermittent streams (such as the Odelouca), highlighting the functional constraints imposed by the Mediterranean habitat templet. Fur- ther, findings from the structural data could be used to develop new, possibly trait based, metrics specific to the study area.

Although macroinvertebrate metrics did not successfully detect the physical impacts acting upon the Odelouca, macroinvertebrate metrics in rapid bioassessment protocols (RBP's) have successfully detected water quality impairment in Iberian and South African Mediterranean streams (Bonada et al., 2006). Macrophyte functional data also did not successfully reflect community changes along the PCA pressure gradients. Forward selection retained a single pressure variable (bank modification) and metrics described only very small amounts of variance. Similar to findings from other Mediterranean systems such as the Tagus River (Ferreira \& Moreira, 1999; Aguiar \& Ferreira, 2005), macrophyte structural data clearly indicated longitudinal species distribution patterns related to changes in land use, water velocity and water availability. Flow and substratum heterogeneity resulting from flood events are fundamental to riparian seed dispersal, recruitment (Dixon, 2003) and habitat heterogeneity which ultimately favour more trophically complex lotic communities (Pearson, Li \& Lamberti, 1992). Aquatic macrophyte and woody riparian communities play a vital role in increasing habitat diversity and creating aquatic refugia for invertebrates and juvenile fish (Pinto et al., 2006) and riparian birds (Jansen \& Robertson, 2001b). Important stands of riparian woody plants species were identified along the tributaries and main channel sites (which will be inundated once the dam is completed) where levels of human intervention were low. Woody riparian species in the lower reaches comprised species typically resistant both to drought and human disturbance, highlighting again the innate covariance that exists between natural factors and stressors in the river landscape. The permanent change in flow patterns caused by the construction of the Odelouca dam will profoundly affect macroinvertebrate and macrophyte community structure and function. This must be redressed via appropriate compensatory measures, such as the establishment of a typologically suitable annual environmental flow regime.

The results of this study agree with the findings of Hering et al. (2006b) in linking larger, more mobile organisms that occupy a range of habitats with environmental and pressure factors operating at higher spatial scales. Results clearly emphasise the 
importance of birds as indicators of wider river corridor health together with fish as more direct indicators of river health. Marked structural and functional distribution patterns were linked to the major PCA gradients, namely changes in land use, physical impacts to the bankside and channel and habitat quality. Fish community structural and functional changes have been marked following the construction of the cofferdam and flow diversion tunnel between 2001 and 2003. Surveys prior to construction recorded S. aradensis and I. almacai as the two most abundant species, occurring along the entire length of the Odelouca (Pires et al., 2004). RDA ordination biplots from this study clearly illustrate how these species are now confined to the upper reaches where habitat heterogeneity is greater, that the eel $A$. anguilla is more abundant in the lower reaches and that exotic species, previously described as having "no relevance for the fish assemblage", are far more prevalent (Pires et al., 2004) in areas suffering channel modification. Increased incidence of exotic species due to habitat degradation has also been observed in the Guadiana catchment, another Portuguese Mediterranean river system where eight native high conservation status species are known to occur (Collares-Pereira et al., 2000; Bernardo et al., 2003). Mediterranean fish communities tend to be depauperate but highly endemic because of the harsh Mediterranean regime. Native species are well adapted and respond via migration and/or tolerance of residual surface water refugia during the dry season to avoid changes in habitat conditions (Magalhães et al., 2002; Bernardo et al., 2003; Magoulick \& Kobza, 2003; Davey \& Kelly, 2007). Flexibility in habitat use as a response to the strong changes that characterise Mediterranean rivers is another tactic to increase overall survival by avoiding unfavourable habitats, e.g. those prone to scouring during flood or drying during the summer (Godinho, Ferreira \& Cortes, 1997; Godinho et al., 2000; Morán-López et al., 2006). In a study on the effect of multi-year droughts on fish assemblages in the Torgal stream, situated only $40 \mathrm{~km}$ from the Odelouca study area, Magalhães et al. (2007) found little change in species richness and composition metrics but significant variation in individual species abundances in relation to interannual cycles of summer drought severity and the occurrence of rainy springs. Our results from a single snap-shot study confirm the limited application of species richness or diversity metrics and highlight the importance of measures related to the abundance of native or exotic species and feeding or habitat preference. However the latter two traits may vary seasonally and require further study.

Avian structural and functional distribution patterns were strongly associated with habitat quality, changes in landuse and physical disturbance to the bank profile, highlighting the important role the avian community plays in direct riparian quality assessment along the Odelouca. Bird assemblages have been used as indicators of woodland and riparian condition (Bryce et al., 2002; Hinsley et al., 2008), large scale changes in land use (Ormerod et al., 2000) and hydromorphological gradients (Vaughn et al., 2007b). Further, studies on dippers in relation to acidification (Ormerod et al., 1986) and water quality (Feck \& Hall, 2004) have clearly illustrated the link between riparian birds and instream degradation resulting from global and local processes. Although adopting a different analytical approach, Vaughn et al. (2007b) used RHS data and bird census data to identify river bird distribution patterns and longitudinal environmental gradients linked to flow type, bankside and channel vegetation, depositional features and manmade structures. Bryce et al. (2002) used bird based metrics to develop a riparian bird integrity index for an integrated assessment approach including fish and invertebrate indicators and watershed data. The strong response of bird functional data to bankside/riparian habitat fragmentation has also been observed in another Mediterranean river system, the River Sado (Moreira, Saraiva \& Pinto, 1997) and in Australian river systems (Jansen \& Robertson, 2001b). Our results further emphasise the importance of bird communities as effective indicators of the ecological integrity of the wider river landscape (Vaughn et al., 2007b).

This study across several communities was carried out over a single season (spring) in a single year during conditions of full connectivity. Annual and interannual cycle of flooding and subsequent drought in Mediterranean systems influence spatial and temporal cycles in fluvial, biotic and abiotic processes (Gasith \& Resh, 1999; Hooke, 2006), with long term implications for biological communities. These predictable natural processes strongly influence organism group traits, a fundamental tenet of the River Habitat Templet (Townsend \& Hildrew, 1994; 
Magalhães et al., 2002; Bernardo et al., 2003; Bêche \& Resh, 2007a,b; Bonada et al., 2007; Díaz et al., 2008) and have implications concerning the accurate interpretation of community responses to perturbation. These factors must be taken into account for developing and implementing effective mitigation and compensation measures during and following dam construction.

This study has shown how selected organism group functional and structural data can be used to detect redundancy and establish typologically appropriate links with stressors and environmental factors in an intermittent Mediterranean river system. It has also shown that detected gradients can comprise a complex interaction between natural and manmade factors. In the case of the Odelouca, fish and bird metrics and species appear to be reliable indicators of the large scale physical impacts, such as riparian habitat fragmentation, physical impacts to the riverbank and channel and flow disruption. Macroinvertebrate and macrophyte species distribution patterns in relation to flow and large scale change in land use can be applied in the testing and development of a multi-organism, multimetric system (Hering et al., 2006a) to assess the ecological condition of the Odelouca and the effect of future mitigation and compensation measures. The permanently compromised flow regime in a system previously defined by dramatic, seasonal patterns of flood and drought must be taken into consideration once the dam comes into operation. This permanent impact will undoubtedly affect all the organism groups considered in this study, emphasising the importance of temporal studies for the development of appropriate mitigation and compensation measures.

\section{Acknowledgments}

This study was carried out as part of a postdoctoral study funded by the Fundação para a Ciência e Tecnologia (FCT grant number SFRHBPD/26909/2006). Many thanks to Luis Lopes and David Santos for assistance in the field, Dr. Daniel Hering (Institut für Biologie, Essen, Germany) for advice on multivariate analysis techniques. Thanks also to Dr Bernhard Statzner (Laboratoire d'Ecologie des Hydrosystèmes Fluviaux, Université de Lyon, France) and anonymous referees for valuable comments on earlier versions of this manuscript.

\section{References}

Aguiar F.C. \& Ferreira M.T. (2005) Human-disturbed landscapes: effects on composition and integrity of riparian woody vegetation in the Tagus River basin, Portugal. Environmental Conservation, 32, 1-12.

Allan J.D. (2004) Landscapes and riverscapes: the influence of land use on stream ecosystems. Annual Review of Ecology Evolution and Systematics, 35, 257-284.

Allan J.D. \& Johnson L.B. (1997) Catchment-scale analysis of aquatic ecosystems. Freshwater Biology, 37, 107-111.

Allan D., Erickson D. \& Fay J. (1997) The influence of catchment land use on stream integrity across multiple spatial scales. Freshwater Biology, 37, 149-161.

AQEM (1999) The Development and Testing of an Integrated Assessment System for the Ecological Quality of Streams and Rivers throughout Europe using Benthic Macroinvertebrates, pp. 198. Project: EVK1.

Barbour M., Gerritsen J., Snyder B. \& Stribling J. (1999) Rapid Bioassessment Protocols for Use in Streams and Wadeable Rivers: Periphyton, Benthic Macroinvertebrates and Fish, 2nd edn. EPA 841-B-99-002. U.S. Environmental Protection Agency; Office of Water, Washington, DC.

Bêche L.A. \& Resh V.H. (2007a) Short-term climatic trends affect the temporal variability of macroinvertebrates in California "Mediterranean" streams. Freshwater Biology, 52, 2317-2339.

Bêche L.A. \& Resh V.H. (2007b) Biological traits of benthic macroinvertebrates in California mediterranean-climate streams: long-term annual variability and trait diversity patterns. Fundamental and Applied Limnology: Archiv für Hydrobiologie, 69, 1-23.

Bêche L.A., McElravy E.P. \& Resh V.H. (2006) Long-term seasonal variation in the biological traits of benthicmacroinvertebrates in two Mediterranean-climate streams in California, U.S.A. Freshwater Biology, 51, 56-75.

Bernardo J.M., Ilhéu M., Matono P. \& Costa A.M. (2003) Interannual variation of fish assemblage structure in a Mediterranean river: implications of streamflow on the dominance of native or exotic species. River Research and Applications, 19, 521.

Bibby C.J., Hill D.A., Burgess N.D. \& Mustoe S. (2000) Bird Census Techniques. Academic Press, London.

Bonada N., Zamora Muñoz C., Rieradevall M. \& Prat N. (2005) Ecological and historical filters constraining spatial caddisfly distribution in Mediterranean rivers. Freshwater Biology, 50, 781-797.

Bonada N., Dallas H., Rieradevall M., Prat N. \& Day J. (2006) A comparison of rapid bioassessment protocols used in 2 regions with Mediterranean climates, the 
Iberian Peninsula and South Africa. Journal of the North American Benthological Society, 25, 487-500.

Bonada N., Rieradevall M. \& Prat N. (2007) Macroinvertebrate community structure and biological traits related to flow permanence in a Mediterranean river network. Hydrobiologia, 589, 91-106.

Bovee K.D. \& Milhous R.T. (1978) Hydraulic Simulation in Instream Flow Studies: Theory and Technique. Instream flow information paper; no. 5 Fish and Wildlife Service. pp. 131. Office of Biological Services, Fortcollins, Colovado, U.S.A. FWSOBS; 7833.

ter Braak C.J.F. \& Smilauer P. (1998) CANOCO Reference Manual and User's Guide to Canoco for Windows: Software for Canonical Community Ordination (version 4). Microcomputer Power, Ithaca, NY.

Bryce S.A., Hughes R.M. \& Kaufmann P.R. (2002) Development of a bird integrity index: using bird assemblages as indicators of riparian condition. Environmental Management, 30, 294-310.

Coelho M., Bogutskaya N., Rodrigues J. \& CollaresPereira M.J. (1998) Leuciscus torgalensis and L. aradensis, two new cyprinids for Portuguese fresh waters. Journal of Fish Biology, 52, 937-950.

Coelho M., Mesquita N. \& Collares-Pereira M. (2005) Chondrostoma almacai, a new cyprinid species from the Southwest of Portugal, Iberian Peninsula. Folia Zoologica, 54, 201-212.

Collares-Pereira M.J., Cowx I.G., Ribeiro F., Rodrigues J.A. \& Rogado L. (2000) Threats imposed by water resource development schemes on the conservation of endangered fish species in the Guadiana River Basin in Portugal. Fisheries Management and Ecology, 7, 67-178.

Comité Européen de Normaliation (2003) Guidance Standard for the Surveying of Aquatic Macrophytes in Running Waters. Rep. No. EN 14184. European Committee for Standardization, Brussels.

Davey A.J.H. \& Kelly D.J. (2007) Fish community responses to drying disturbances in an intermittent stream: a landscape perspective. Freshwater Biology, 52, 1719-1733.

Díaz A.M., Suárez Alonso M.L. \& Vida-Abarca Gutiérrez M.R. (2008) Biological traits of stream macroinvertebrates from a semi-arid catchment: patterns along complex environmental gradients. Freshwater Biology, 53, 1-21.

Dixon M. (2003) Effects of flow pattern on riparian seedling recruitment on sandbars in the Wisconsin River, Wisconsin, U.S.A. Wetlands, 22, 125-139.

Feck J. \& Hall R.O. Jr (2004) Response of American dippers (Cinclus mexicanus) to variation in stream water quality. Freshwater Biology, 49, 1123-1137.

Feio M.J., Almeida S.F.P., Craveiro S.C. \& Calado A.J. (2007) Diatoms and macroinvertebrates provide consistent and complementary information on environmental quality. Fundamental and Applied Limnology Archiv für Hydrobiologie, 168, 247-258.

Feld C. \& Hering D. (2007) Community structure or function: effects of environmental stress on benthic macroinvertebrates at different spatial scales. Freshwater Biology, 52, 1380-1399.

Fernandes M., Ferreira M.T., Hughes S.J., Cortes R., Santos J. \& Pinheiro J. (2007) Preclassification of ecological quality in the Odelouca catchment area and its use in restoration guidelines. Recursos Hidricos (Associação Portuguesa de Recursos Hidricos), 28, 15-24.

Ferreira M.T. \& Moreira I.S. (1999) River plants from an Iberian basin and environmental factors influencing their distribution. Hydrobiologia, 415, 101-107.

Frissell C.A., Liss W.J., Warren C.E. \& Hurley M.D. (1986) A hierarchical framework for stream classification: viewing streams in a watershed context. Environmental Management, 10, 199-214.

Furse M., Hering D., Moog O. et al. (2006) The Ecological Status of European Rivers: Evaluation and Intercalibration of Assessment Methods. Hydrobiologia, 566, 3-9.

Gasith A. \& Resh V.H. (1999) Streams in Mediterranean climate regions: abiotic influences and biotic responses to predictable seasonal events. Annual Review of Ecology and Systematics, 30, 51-81.

Gauch H.G.J. (1982a) Multivariate Analysis in Community Ecology. Cambridge University Press, New York.

Godinho F.N., Ferreira M.T. \& Cortes R.V. (1997) Composition and spatial organization of fish assemblages in the lower Guadiana basin, southern Iberia. Ecology of Freshwater Fish, 6, 134-143.

Godinho F.N., Ferreira M.T. \& Santos J.M. (2000) Variation in fish community composition along an Iberian river basin from low to high discharge: relative contributions of environmental and temporal variables. Ecology of Freshwater Fish, 9, 22-29.

Griffith M.B., Husby P., Hall R.K., Kaufmann P.R. \& Hill B.H. (2003) Analysis of macroinvertebrate assemblages in relation to environmental gradients among lotic habitats of California's Central Valley. Environmental Monitoring and Assessment, 82, 281-309.

Hawkins C.P., Norris R.H., Gerritsen J., Hughes R.M., Jackson S.K., Johnson R.K. \& Stevenson R.J. (2000) Evaluation of the use of landscape classifications for the prediction of freshwater biota: synthesis and recommendations. Journal of the North American Benthological Society, 19, 541-556.

Hering D., Moog O., Sommerhäuser M., Vlek H., Birk S., Buffagni A., Feld C. \& Ofenböck T. (2002) Manual for the application of the AQEM system. A comprehensive method to assess European streams using benthic 
macroinvertebrates, developed for the purpose of the Water Framework Directive. Version 1.0, February 2002. AQEM CONSORTIUM.

Hering D., Moog O., Sandin L. \& Verdonschot P.F.M. (2004) Overview and application of the AQEM assessment system. Hydrobiologia, 516, 1-20.

Hering D., Feld C., Moog O. \& Ofenböck T. (2006a) Cook book for the development of a Multimetric Index for biological condition of aquatic ecosystems: experiences from the European AQEM and STAR projects and related initiatives. Hydrobiologia, 566, 311-324.

Hering D., Johnson R.K. \& Buffagni A. (2006b) Linkingorganism groups - major results from the STAR project. Hydrobiologia, 566, 109-113.

Hering D., Johnson R., Kramm S., Schmutz S., Szoszkiewicz K. \& Verdonschot P. (2006c) Assessment of European streams with diatoms, macrophytes, macroinvertebrates and fish: a comparative metricbased analysis of organism response to stress. Freshwater Biology, 51, 1757-1785.

Hinsley S.A., Hill R.A., Bellamy P.E., Harrison N.M., Speakman J.R., Wilson A.K. \& Ferns P.N. (2008) Effects of structural and functional habitat gaps on breeding woodland birds: working harder for less. Landscape Ecology, 23, 615-626.

Hooke J.M. (2006) Human impacts on fluvial systems in the Mediterranean region. Geomorphology, 79, 311-335.

Hughes S.J., Ferreira M.T. \& Cortes R.M.V. (2008) Hierarchical spatial patterns and drivers of change in benthic macroinvertebrate communities in an intermittent Meditteranean river. Aquatic Conservation: Marine and Freshwater Ecosystems, 18, 742-760.

Instituto Nacional da Água (2008a) Manual para a avaliação biológica da qualidade da água em sistemas fluviais Segundo a Directiva Quadro da Água: protocolo de amostragem e análise para os macroinvertebrados. Ministério do Ambiente, Ordenamento do Território e do Desenvolvimento Regional, Instituto Nacional da Água, Lisboa, 23 pp.

Instituto Nacional da Água (2008b) Manual para a avaliação biológica da qualidade da água em sistemas fluviais Segundo a Directiva Quadro da Água: protocolo de amostragem e análise para a fauna piscícola. Ministério do Ambiente, Ordenamento do Território e do Desenvolvimento Regional, Instituto Nacional da Água, Lisboa, 15 pp.

Instituto Nacional da Água (2008c) Manual para a avaliação biológica da qualidade da água em sistemas fluviais Segundo a Directiva Quadro da Água: protocolo de amostragem e análise para os macrófitos. Ministério do Ambiente, Ordenamento do Território e do Desenvolvimento Regional, Instituto Nacional da Água, Lisboa, 17 pp.
Jansen A. \& Robertson A.I. (2001b) Riparian bird communities in relation to land management practices in floodplain woodlands of south-eastern Australia. Biological Conservation, 100, 173-185.

Johnson R.K. \& Hering D. (2009) Response of taxonomic groups in streams to gradients in resource and habitat characteristics. Journal of Applied Ecology, 46, 175-186.

Johnson R.K., Hering D., Furse M. \& Clarke R.T. (2006a) Detection of ecological change using multiple organism groups: metrics and uncertainty. Hydrobiologia, 566, 115137.

Lyons J. (1996) Patterns in the species composition of fish assemblages among Wisconsin streams. Environmental Biology of Fishes, 45, 329-341.

Magalhães M.F., Beja P., Canas C. \& Collares Pereira M.J. (2002) Functional heterogeneity of dry-season fish refugia across a Mediterranean catchment: the role of habitat and predation. Freshwater Biology, 47, 1919-1934.

Magalhães M.F., Beja P., Schlosser I.J. \& Collares Pereira M.J. (2007) Effects of multi-year droughts on fish assemblages of seasonally drying Mediterranean streams. Freshwater Biology, 52, 1494-1510.

Magnan P. \& Rodriguez M.A. (1994) Dietary variation in a freshwater fish species: relative contributions of biotic interactions, abiotic factors and spatial structure. Canadian Journal of Fisheries and Aquatic Sciences, 51, 2856-2865.

Magoulick D.D. \& Kobza R.M. (2003) The role of refugia for fishes during drought: a review and synthesis. Freshwater Biology, 48, 1186-1198.

May J. \& Brown L. (2002) Fish communities of the Sacramento river Basin: implications for the conservation of native fishes in the Central Valley, California. Environmental Biology of Fishes, 63, 373-388.

Morán-López R., Da Silva E., Pérez-Bote J.L. \& Corbacho Amado C. (2006) Associations between fish assemblages and environmental factors for Mediterranean-type rivers during summer. Journal of Fish Biology, 69, 15521569.

Moreira I., Saraiva M. \& Pinto I. (1997) Assessing the conservation value of a Mediterranean River Basin (Sado - Portugal). In: Freshwater Quality: Defining the Indefinable? (Eds P.A.H. Boon \& D.L. Howell), pp. 290 298. HMSO, Edinburgh.

O'Connor R., Walls T.E. \& Hughes R.M. (2000) Using multiple taxonomic groups to index the ecological condition of lakes. Environmental Monitoring and Assessment, 61, 207-228.

Ormerod S.J., Allenson N., Hudson D. \& Tyler S.J. (1986) The distribution of breeding dippers (Cinclus cinclus (L.) Aves in relation to stream acidity in upland Wales. Freshwater Biology, 16, 501-507. 
Ormerod S.J., Brewin P.A., Buckton S.T., Jüttner I. \& Manel S. (2000) Testing the Himalayan degrdation hypothesis: does catchment land use affect river biota. Verhandlungen der Internationalen Vereinigung für theoretische und angewandte Limnologie, 27, 895-900.

Pearson T.N., Li H.W. \& Lamberti G.A. (1992) Influence of habitat complexity on resistance to flooding and resilience of stream fish assemblages. Transactions of the American Fisheries Society, 121, 427-436.

Pinto P., Morais M., Ilhéu M. \& Sandin L. (2006) Relationships among biological elements (macrophytes, macroinvertebrates and ichthyofauna) for different core river types across Europe at two different spatial scales. Hydrobiologia, 566, 75-90.

Pires A.M., da Costa L.M., Alves M.J. \& Coelho M.M. (2004) Fish assemblage structure across the Arade basin (Southern Portugal). Cybium, 28, 357-365.

Poff N.L. (1997) Landscape filters and species traits: towards mechanistic understanding and prediction in stream ecology. Journal of the North American Benthological Society, 16, 391-409.

Raven P.J., Fox P.J.A., Everard M., Holmes N.T.H. \& Dawson F.D. (1997) River Habitat Survey: a new system for classifying rivers according to their habitat quality. In: Freshwater Quality: Defining the Indefinable? (Eds P.A.H. Boon \& D.L. Howell), pp. 215-234. HMSO, Edinburgh.

Resh V.H. (2008) Which group is best? Attributes of different biological assemblages used in freshwater biomonitoring programs. Environmental Monitoring and Assessment, 138, 131-138.

Santos J.M. \& Ferreira M.T. (2008) Microhabitat use by endangered Iberian cyprinids nase Iberochondrostoma almacai and club Squalius aradensis. Aquatic Sciences, 70, 272-281.

Southwood T.R.E. (1977) Habitat, the templet for ecological strategies. Journal of Animal Ecology, 46, 337-365.
Southwood T.R.E. (1988) Tactics, strategies, and templets. Oikos, 52, 3-18.

Statzner B., Dolédec S. \& Hugueny B. (2004) Biological trait composition of European stream invertebrate communities: assessing the effects of various trait filter types. Ecography, 27, 470-488.

Townsend C.R. \& Hildrew A.G. (1994) Species traits in relation to a habitat templet for river systems. Freshwater Biology, 31, 265-275.

Townsend C.R., Hildrew A.G. \& Francis J. (1989) Community structure in some southern English Streams: the influence of physicochemical factors. Freshwater Biology, 13, 521-544.

Vaughn I.P., Noble D.G. \& Ormerod S.J. (2007b) Combining surveys of river habitats and river birds to appraise riverine hydromorphology. Freshwater Biology, 52, 2270-2284.

(Manuscript accepted 6 May 2009)

\section{Supporting Information}

Additional Supporting Information may be found in the online version of this article:

Appendix S1. (a) Final list of metrics calculated for each organism group and retained following Spearman correlation analysis and PCA. (b) List of taxa recorded for each organism group with individual taxon codes and distribution data ( $\%$ of total abundance) in the upper reaches, lower reaches and tributaries of the Odelouca River $(\bullet 1-35 \%$; $\bullet 36-60 \% \bullet>61 \%)$.

Please note: Wiley-Blackwell are not responsible for the content or functionality of any supporting materials supplied by the authors. Any queries (other than missing material) should be directed to the corresponding author for the article. 